\title{
Differential behavioural and endocrine responses of common voles (Microtus arvalis) to nest predators and resource competitors
}

\author{
Monique Liesenjohann ${ }^{1 *}$, Thilo Liesenjohann ${ }^{1}$, Rupert Palme ${ }^{2}$ and Jana Anja Eccard ${ }^{1}$
}

\begin{abstract}
Background: Adaptive behavioural strategies promoting co-occurrence of competing species are known to result from a sympatric evolutionary past. Strategies should be different for indirect resource competition (exploitation, e.g., foraging and avoidance behaviour) than for direct interspecific interference (e.g., aggression, vigilance, and nest guarding). We studied the effects of resource competition and nest predation in sympatric small mammal species using semi-fossorial voles and shrews, which prey on vole offspring during their sensitive nestling phase. Experiments were conducted in caged outdoor enclosures. Focus common vole mothers (Microtus arvalis) were either caged with a greater white-toothed shrew (Crocidura russula) as a potential nest predator, with an herbivorous field vole (Microtus agrestis) as a heterospecific resource competitor, or with a conspecific resource competitor.

Results: We studied behavioural adaptations of vole mothers during pregnancy, parturition, and early lactation, specifically modifications of the burrow architecture and activity at burrow entrances. Further, we measured pre- and postpartum faecal corticosterone metabolites (FCMs) of mothers to test for elevated stress hormone levels. Only in the presence of the nest predator were prepartum FCMs elevated, but we found no loss of vole nestlings and no differences in nestling body weight in the presence of the nest predator or the heterospecific resource competitor. Although the presence of both the shrew and the field vole induced prepartum modifications to the burrow architecture, only nest predators caused an increase in vigilance time at burrow entrances during the sensitive nestling phase.

Conclusion: Voles displayed an adequate behavioural response for both resource competitors and nest predators. They modified burrow architecture to improve nest guarding and increased their vigilance at burrow entrances to enhance offspring survival chances. Our study revealed differential behavioural adaptations to resource competitors and nest predators.
\end{abstract}

Keywords: Behavioural adaptations, Small mammals, Interspecific interactions, Nest predation, Stress response, Faecal corticosterone metabolites, Burrow system, Shrews, Voles

\section{Background}

Communities are shaped by interspecific interactions and specific adaptations, depending on the nature of the interaction (direct or indirect), allowing coexistence [1]. Effects of competition might be masked by behavioural adaptations as a result of a shared evolutionary history. Studies of interspecific competition have mainly focused on how indirect exploitation competition affect behaviour,

\footnotetext{
* Correspondence: monique.liesenjohann@uni-potsdam.de

'Department of Animal Ecology, University of Potsdam, Maulbeerallee 1,

D-14469 Potsdam, Germany

Full list of author information is available at the end of the article
}

e.g., via territoriality and foraging strategy [2], and have neglected the implications of direct interference for community structure [3] and evolution [4].

Direct antagonistic interactions in competition for food, space, nest sites, or mating partners can be very costly, especially if the competition reduces individual fitness (direct interference) [3,5-7]. Aggressive behavioural confrontations between competing species are likely if adults prey on each others offspring [8]. Interference may result from resource-related aggression between heterospecific or conspecific individuals with potential effects on niche use and community structure (e.g., dominance or exclusion)

\section{Biomed Central}


[4]. Nest predation has been considered a special case of direct interference via interspecific killing $[3,9]$. It is a significant source of offspring mortality and can strongly affect parental life history strategies $[10,11]$.

Although numerous population studies have shown that nest predation is widespread in animal communities [12-14], its importance as an evolutionary force has been neglected $[15,16]$. Recent studies on avian breeding biology demonstrate that the direct fitness effects of nest predation can drive evolution [10,12,17,18]. Safety of nest sites and optimised breeding conditions are key intrinsic components of breeding habitat quality [15,19]. Adults should adapt their behaviour to predation risk $[18,20]$ by, e.g., choosing concealed nest sites [19], adjusting clutch size or nestling period [12], and temporally partitioning foraging activity $[21,22]$.

Comprehensive knowledge about adaptive strategies against nest predation in mammals is lacking. Yet defence of a nest and its vulnerable young is a powerful explanation for the ultimate function of female aggression and territoriality, which is most intense during lactation and near the nest site [23]. In addition, nests (in birds) or burrows (in mammals) serve as micro-refuges from predators and therefore have anti-predatory benefits for the adult as well [24].

\section{Parental anti-nest predatory behaviour}

According to parental investment theory, parents must trade off the benefits of investment into current offspring with possible negative effects on their future inclusive fitness [13,25-27]. In addition, parents might suffer extra costs of defending offspring against predators, including time, energy, and missed opportunity costs [26,28,29]. Short-term adjustments are often trade-offs between behaviours, e.g., predator avoidance and foraging [30], and escalate in defending offspring against predators or infanticidal conspecifics $[8,23,26,31,32]$. The degree of escalation is influenced by offspring vulnerability and reproductive value to the parent $[13,25]$. Female rodents become more aggressive during their pregnancy [33]. Female European rabbits (Oryctolagus cuniculus) increase vigilance during late pregnancy to minimise predation [34]. In mice, mothers successfully defend their nestling pups against infanticidal conspecifics [32]. Attacks on pups decrease rapidly after they reach a less vulnerable stage [35]. Maternal defence behaviour against rattlesnakes declines in California ground squirrels as snake activity declines when pups grow older [31].

According to the "harm to offspring hypothesis" of Dale et al. [36], the level of parental predation risk-taking is adjusted according to the harm the offspring will suffer without parental care. Most vulnerable are altricial nestlings incapable of escaping and defending themselves [13,36,37]. Predation risk is highest when the parents are away (e.g., during foraging trips) [32,33,37,38]. In response, parents might alter their foraging time (e.g., reducing activity) or seek temporal or spatial foraging refuges to decrease risk [39,40]. Cresswell [41] showed that nesting blackbirds altered their nest defence behaviour to compensate for predation risk demonstrating that parental behavioural flexibility in response to predation can yield fitness benefits [42] compared with fixed strategies [18]. For semi-fossorial mammals, the morphology and complexity of burrows have high defence value for nestlings and thereby fulfil an anti-predator function, especially for animals with helpless altricial young [24,43]. Hunting intruders might be confused by very complex burrow systems $[44,45]$. Some species dig special parturition chambers in addition to the main burrow (e.g., European rabbits, [46]) and plug them to minimise predation (e.g., Columbian ground squirrel, Urocitellus columbianus, [31]). Increased vigilance (e.g., high scanning rates in European rabbits $[47,48])$ at burrow entrances and adjusting burrow attributes (diameters, depths, or lengths of the burrow, tunnels, and nest chambers) may further lower the risk of nest predation $[17,45,49]$.

\section{Physiological stress responses to nest predation risk}

Physiological responses in stressful situations, e.g., encounters of prey with predators, are evolutionarily conserved and represent a widespread and fundamental mechanism for ecosystem functioning in animal systems [40,50]. Predator-induced changes in stress hormone metabolites associated with acute or chronic risks (reviewed in [40]) aim to increase survival [51]. Animals without adequate alternative defence responses (e.g., alteration of life histories, defensive morphologies) to mitigate predation risk must engage in costly physiological responses [40]. Elevated plasma glucocorticoids, or their faecal metabolites, are often measured as indicators of such physiological stress responses [50,52-55].

\section{Study system and hypotheses}

Here we compare behavioural strategies among different interaction types: interspecific resource competition, intraspecific interference competition, and interspecific nest predation. We used a small mammal study system including the semi-fossorial common voles (Microtus arvalis) as focus animals, the greater white-toothed shrews (Crocidura russula) as potential nest predators, and field voles (Microtus agrestis) as interspecific competitors. All three species coexist in many habitats of the northern hemisphere, overlapping in their common habitat and, to a smaller extent, in their diets [56-58]. Voles live in large burrow systems with underground tunnels and corresponding runway systems above ground. Shrews explore vole tunnel systems to search for invertebrate food [59]. Because of the limited space underground, shrews may 
react aggressively when encountering tunnel inhabitants. Additionally, they can act as nest predators on altricial vole nestlings by plundering their easily accessible nest chambers [60]. This shrew behaviour might intensify during environmentally-adverse seasons when invertebrate food is scarce, e.g., in autumn [61].

To protect vulnerable altricial nestlings from nest predators, voles should have evolved anti-nest predator strategies to secure their reproductive success. Getz et al. [38] reported nest defences in two American vole species, Microtus pennsylvanicus and $M$. ochrogaster, even against larger shrew species, e.g., Blarina brevicauda. Shrews only successfully preyed on nests when vole mothers were absent on foraging trips [38].

What kinds of parental behavioural strategies can secure nestling survival and allow the coexistence of competing species in a nest predator-prey system? How do these strategies differ from responses to non-nest predator antagonists?

(A) We hypothesised that vole mothers adjust their burrow systems in response to antagonists [45]. If she encounters a nest predator during pregnancy, we expected to find different nest architectures at parturition than in the absence of predators.

(B) We further hypothesised that vole mothers react to nest predation risk by altering their time budgets and habitat use. To guard vulnerable nestlings, vole mothers should increase vigilance and nest guarding behaviour (e.g., at burrow entrances), especially during the first sensitive nestling phase. We expected guarding behaviour to be more intense in the presence of a potential nest predator than in the presence of an inter- or intraspecific resource competitor. In addition, if guarding behaviour incurs extra costs for vole mothers, e.g., owing to shortened foraging periods, we expected that to be reflected in the mother's or nestlings' body conditions.

If vole mothers exhibit physiological stress reactions concomitant to these behavioural reactions (A and $\mathrm{B}$ ), we expected levels of faecal corticosterone metabolites (FCM) to correlate to the presence or absence of different antagonists.

(C) Thus, we hypothesised that the levels of stress hormone metabolites in expectant vole mothers increased when they encountered shrews as nest predators.

\section{Results}

\section{Behavioural adaptations: burrow architecture}

The numbers of burrow entrances built by vole mothers were significantly influenced by the type of antagonist
(GLM, $F_{2,30}=16.05, P<0.001$; Figure $\left.1 \mathrm{~A}\right)$. In the NP treatment, they built fewer entrances $(2.1 \pm 0.19$, mean $\pm \mathrm{SE})$ compared with the $\mathrm{RC}(3.0 \pm 0.58)$ or $\mathrm{C}$ $(5.8 \pm 0.56)$ treatments. The depth of the nest site was also influenced by antagonist type (ANOVA, $F_{2,29}=18.09$, $P<0.001$; Figure 1B). Mothers built nests closer to the surface in the NP $(14.6 \pm 1.1 \mathrm{~cm})$ than in the RC $(22.5 \pm 2.3 \mathrm{~cm})$ or $\mathrm{C}(29.5 \pm 1.9 \mathrm{~cm})$ treatments.

\section{Behavioural adaptations: activity in burrow entrances}

The treatment species had a significant effect on the mothers' activity in the burrow entrances (MANOVA, Wilks' lambda $\left.=0.079, F_{6}, 30=12,84, P<0.001\right)$. Vole mothers in the NP treatment spent more time in entrances (4.9 \pm 0.2 antenna readings per second) compared with those in the $\mathrm{RC}(2.9 \pm 0.7$ readings $/ \mathrm{sec})$ or $\mathrm{C}$ $(2.5 \pm 0.4$ readings $/ \mathrm{sec})$ treatments (ANOVA, $F_{2,17}=80.1$, $P<0.001$; Figure 2). The mean number of readings/bout (ANOVA, $F_{2,17}=0.863, P=0.44$ ) and the mean number of seconds vole mothers spent in entrances per bout (ANOVA, $F_{2,17}=2.14, P=0.15$ ) were not influenced by the antagonist species.

We also recorded all treatment species entering the tunnel entrances (Table 1). Seventy-eight per cent of the shrews (NP) entered the burrow systems, while only $50 \%$ of the field voles (RC) and $43 \%$ of common voles (C) did so, but the latter two species visited the burrow system more often per replicate than did the shrews (Table 1).

\section{Stress hormone level}

We found no difference in the baseline amount of FCMs before the treatments (GLM, $F=0.138, d f=2, P=0.872$; Figure 3). Under treatment conditions (sampling $I$ and $I I$ ), FCMs were affected by an interaction of treatment and sampling (GLM, treatment $\times$ sampling: $F=7.636, d f=2$, $P=0.002$; treatment: $F=4.262, d f=2, P=0.023$; sampling: $F=1.106, d f=1, P=0.301$; Figure 3$)$. Mothers in NP treatments had a higher FCM levels around parturition (sampling $I$ ) compared with the other treatments (Bonferroni corrected post hoc comparisons, NP I / RC I: $P=0.001$, NP $I / C I: P=0.009)$ and compared with the postpartum period (sampling II) (NP I / NP II: $P=0.014$ ). The FCM of vole mothers did not differ any more between treatments when nestlings were $5 \mathrm{~d}$ old (sampling II). Nonsignificant post hoc results are not displayed.

\section{Maternal body condition and offspring survival}

We found no influence of treatment on the vole mother's body weight (MANOVA, Wilks' lambda $=0.899, F_{6,56}=$ $0.51, P=0.79$ ), either prepartum (ANOVA, $F_{2,}$, $30=0.39$, $P=0.68$ ) nor postpartum (ANOVA, $F_{2,30}=0.03, P=0.97$ ). We also found no influence of antagonist species on offspring survival (MANOVA, Wilks' lambda $=0.959$, $\left.F_{4,48}=0.255, P=0.91\right)$. Both the number of vole nestlings 


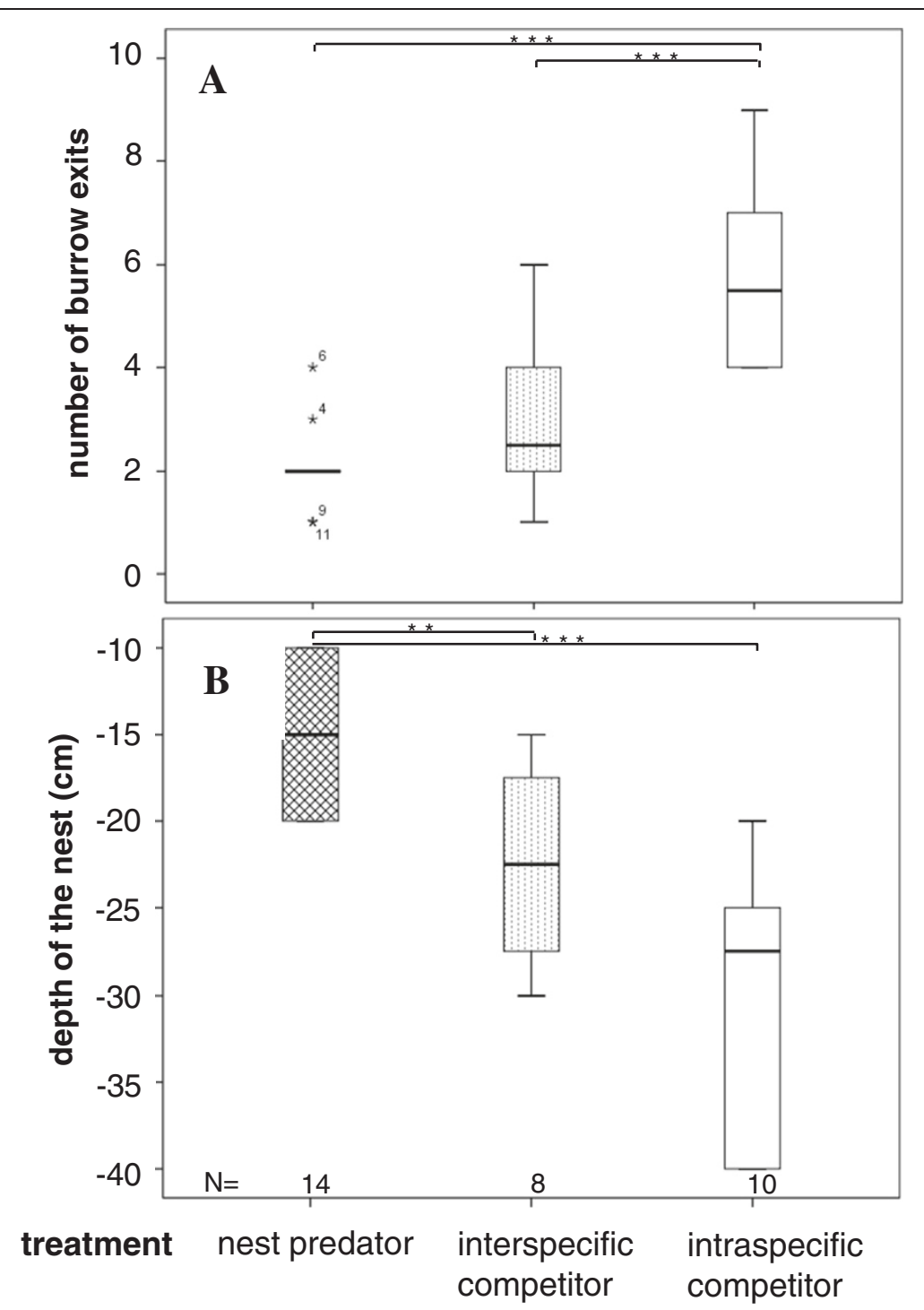

Figure 1 Number of the burrow entrances (A) and the depth of the nest (B) of vole females (Microtus arvalis) in the presence of a nest predator (NP, Greater white toothed shrew, Crocidura russula), or a interspecific resource competitor (RC, female field vole, M. agrestis) or a intraspecific competitor control (C, female common vole, $\mathbf{M}$. arvalis). All burrow entrances were counted at day 22 of the experiment when vole nestlings were 3 days old. Please note that the $y$ axis in (B) is negatively scaled $(0=$ ground level), visualizing the direction of digging into the ground.

(ANOVA, $F_{2,25}=0.193, P=0.83$ ) and nestling body weight (ANOVA, $F_{2,25}=0.371, P=0.69$ ) were independent of antagonist species.

\section{Discussion}

We investigated behavioural and physiological responses of vole mothers to different intra-nest interactions: nest predation, interspecific resource competition, and intraspecific competition. Nest predators affected burrowing behaviour and passage activity at burrow entrances as well as physiological stress responses. The presence of neither a potential nest predator nor a competitor species altered reproductive success. Furthermore, nestlings in all treatments were in good condition. These results indicate that vole mothers seem to perceive shrews as a threat and adequately respond to their presence. Treatment animals of all antagonist species visited the vole mothers' burrow system several times. Vole mothers were apparently successful in defending their nestlings against potential nest predation attempts.

\section{Adaptive anti-nest predatory strategies}

Pregnant common voles responded to the presence of a potential nest predator or a resource competitor with different nest site preparations. Contrary to findings on African gerbil (Tatera brantsii [44]) and prairie vole 


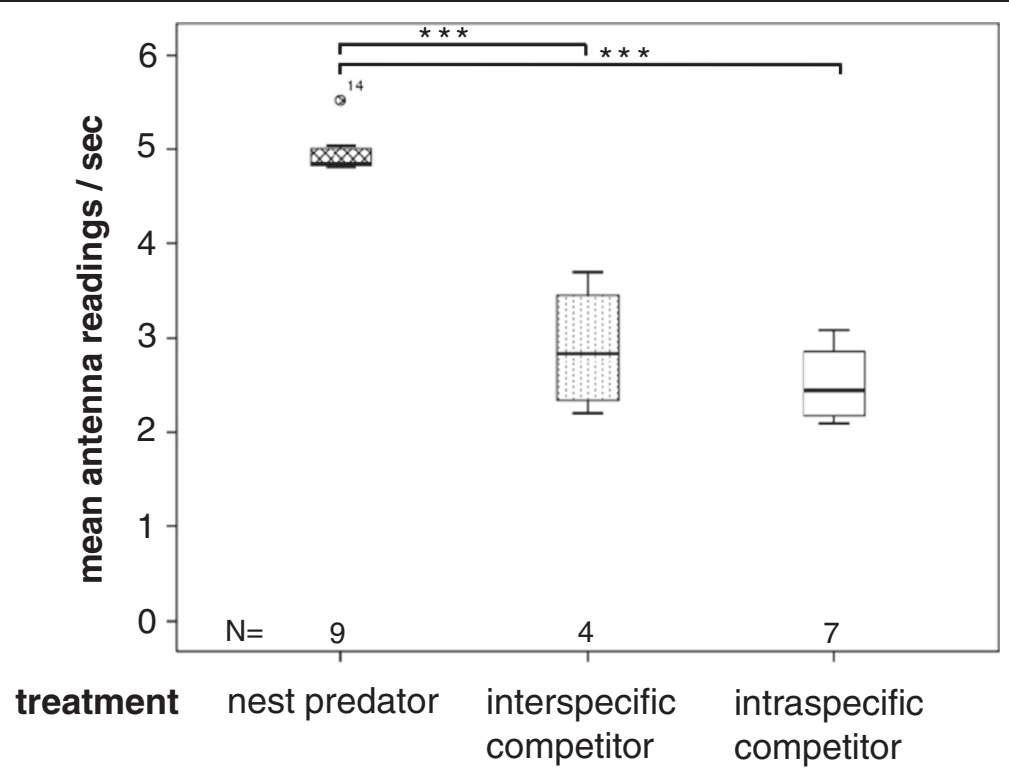

Figure 2 Vole mother's (Microtus arvalis) time spent in their burrow entrances (during $\mathbf{3 6}$ hours). This variable was measured as mean number of antenna readings per second (possible maximum $=6$ readings per second, indicating that the animal sits in the antenna ring; $<3$ readings indicate a fast passage) in the presence of a nest predator (NP, shrew, Crocidura russula), a interspecific resource competitor (RC, field vole, M. agrestis), or a intraspecific competitor control individual (C). Data derived from circular antennas fixed at each burrow entrance connected to automatic transponder reading stations.

(Microtus ochrogaster [45]) mothers, which build complex burrow systems to confuse predators or to hide nestlings [44], the common voles in our study constructed simpler burrow systems in the presence of nest predators, but not when a competitor species was present. Nest defence might be more efficient in a basic burrow system than in a complex one. Additionally, simpler refuges might help to reduce interactions with antagonists and avoid unnecessary energetic costs $[26,28]$, as in complex tunnel systems. Another explanation might be that pregnant females without nest predation pressure stayed in their prepartum burrow, while pregnant females threatened with a nest predator may have dug a new, isolated nest site [45], as shown in laboratory rats [62] and European rabbits [46]. By preparing the nest site prepartum (e.g., by plugging nest burrow entrances [63]), mothers might try to avoid spending energy postpartum in digging and guarding the

Table 1 Summary of antagonist species visits to vole mothers' burrow systems

\begin{tabular}{lccc}
\hline $\begin{array}{l}\text { Treatment } \\
\text { animal }\end{array}$ & $\begin{array}{c}\text { Replicates } \\
\text { in total }\end{array}$ & $\begin{array}{c}\text { Number of replicates } \\
\text { with visits of treatment } \\
\text { individuals }\end{array}$ & $\begin{array}{c}\text { Mean visits } \\
\text { per replicate }\end{array}$ \\
\hline Nest predator & 9 & 7 & 1.5 \\
$\begin{array}{l}\text { Interspecific resource } \\
\text { competitor }\end{array}$ & 4 & 2 & 2.0 \\
Intraspecific control & 7 & 3 & 2.0 \\
\hline
\end{tabular}

The number of antagonist visits to the vole burrow was recorded using automatic transponder-reading antennas inserted into tunnel entrances. nestlings. These findings agree with the "harm to offspring" hypothesis $[13,33,36,37]$, which predicts that mothers should minimise periods of vulnerability during parental absence (e.g., foraging, movement activities, and digging) [33]. Common vole burrow traits in the presence of a heterospecific competitor might reflect a general necessity for nestling protection against possible intruders. Harper and Batzli [45] found no strong effect on the burrowing behaviour of prairie voles by the presence of heterospecific meadow voles. Although heterospecific resource-related aggression can have similar consequences to predation effects (e.g., competitor exclusion) [4], vole mothers seemed to differentiate between the risks of heterospecific aggression and nest predation.

Nest guarding and vigilance behaviour as indicators of the perceived predation risk suggest that vole mothers have adapted to shrews as nest predators through a shared evolutionary past. Only in the presence of shrews did vole mothers spent long time periods in the burrow entrances. Increase of vigilance is a common response to predator odour $[48,64,65]$. For example, female European rabbits increased their vigilance (scanning rates), especially during late pregnancy, to deter attacks by potential predators [34].

Female mammals must allocate their time among maternal care, foraging, and vigilance, especially during the first days of nestling life. In some species, this trade-off adversely affects the condition of pregnant or lactating females [66-68]. We found no effect of increased vigilance 


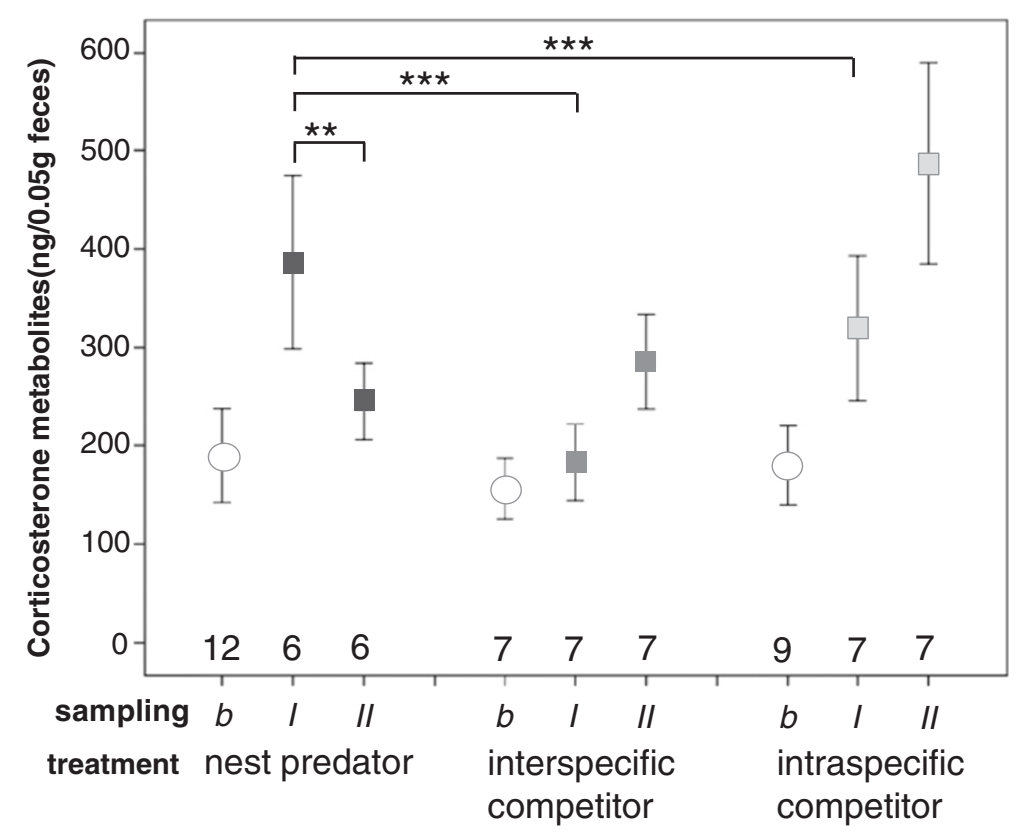

Figure 3 Amount of corticosterone metabolites in the fecal samples of common vole mothers (Microtus arvalis). Mothers were either treated with a nest predator (NP, shrew, Crocidura russula), an interspecific resource competitor (RC, field vole, M. agrestis) or an intraspecific competitor control individual (C). Samples were taken at three reproductive phases (sampling b, I, I) within one reproduction cycle of each female common vole. $b$ : baseline; taken after 3 days of habituation to enclosures (at day 15 of common voles' pregnancy) before treatment. I: Sample taken around parturition and 3 days after adding treatment animals to enclosures (at day 18 of pregnancy). II: Sample taken with having 5 days old nestlings.

in the shrew treatment on neither maternal nor nestling body weight. Other studies with simulated predation risks also demonstrated stable food intake, despite increased vigilance $[34,48,69]$. Vigilance and foraging during the energetically-demanding reproductive phase are therefore not mutually exclusive, and mothers in our experiment were able to successfully protect their young against nest predators without suffering energetic costs. This finding might not apply under natural conditions, e.g., if food for shrews is scarce and shrews exert higher predation pressure on vole nestlings.

\section{Physiological stress responses to nest predation}

The physiological stress response to the presence of a nest predator during late pregnancy was higher than in other competitor treatments or in the postpartum phase. A few days after parturition, the levels of FCMs decreased almost to pre-treatment baseline levels. Female rodents were most aggressive around parturition, and aggression levels decreased thereafter [33]. Pregnant laboratory rats, for example, more aggressively defend their nests against conspecific males and females [62]. Our results probably indicate a correlation between aggression and stress hormone levels and suggest that hormonal-mediated adaptive behavioural strategies help to minimise the risk of nest predation.
Vole mothers in the presence of a heterospecific or conspecific competitor had higher FCM levels during the postpartum phase compared with the nest predator treatment and the prepartum phase. Increased resource competition ('exploitative competition') during lactation associated with higher aggression levels against competitors [4] might have caused the elevated FCM levels.

\section{Conclusions}

Vole mothers in our study showed behavioural and hormonal reactions specific to antagonist species. The presence of a nest predator induced flexible behavioural adaptations during pregnancy to secure subsequent offspring survival, including modifications of the burrow architecture in combination with increased vigilance and nest guarding. Behavioural adaptations seem to be successful maternal strategies to balance typical postpartum parental investment trade-offs (e.g., time for foraging and nest defence) and to secure fitness. Our results suggested differential adaptations as a result of co-evolution with a nest predator compared with resource competitors. Voles and shrews do not only compete in a 'race for space' (interference competition, [61]) but also in an 'arms race' in predatory and anti-predatory behaviour. 


\section{Methods}

\section{Study site}

We conducted the experiment in eight caged outdoor enclosures $(5 \times 6 \mathrm{~m})$ at the Department of Animal Behaviour at the University Bielefeld, Germany $\left(52^{\circ} 02^{\prime} \mathrm{N}, 8^{\circ}\right.$ $\left.29^{\prime} \mathrm{E}\right)$. Enclosures were caged with micromesh to prevent avian and ground predation and equipped with multiplecapture live traps (six per each enclosure; Ugglan, Grahnab, Gnosjö, Sweden). The ground was densely covered with grassland herbs.

\section{Experimental schedule and animals}

Female common voles were used as focus animals and observed during late pregnancy, parturition, and early lactation. The common voles were wild-caught or laboratoryborn multiparous individuals and each was used only once during the experiment. Age group and origin of both focus and treatment animals were equally distributed over experimental treatments and replicates. We used different antagonists as treatment animals: greater white toothed shrews were potential nest predators (NP), non-pregnant female field voles were interspecific resource competitors $(\mathrm{RC})$, and non-pregnant female common voles were intraspecific resource competitors (control, C). The study design involved a constant competitor density to allow comparisons among competitor types rather than whether shrews had an effect at all (for a discussion of additive or replacement designs see $[1,70])$. We expected vole females with a conspecific female to behave similarly to being alone because common voles are very sociable and not solitary or exclusively territorial.

Seven experimental runs with parallel enclosure replicates were carried out between June and September 2008, the main reproductive phase of the common vole. There were 32 realised enclosure replicates in total, with one focus female each. One run consisted of at least two parallel enclosure replicates including one nest predator and one resource competitor treatment (NP, 14 replicates; RC, 8 replicates; and $C, 10$ replicates).
All focus and treatment animals were individually marked with passive integrated transponders (PIT ID100; Trovan $\left.^{\circ}\right)$. Because shrews are very sensitive to trapping stress, we checked mealworm-baited traps every hour. Common voles, field voles, and shrews were caged separately to prevent odour exchange prior to the experiment. Shrews were fed mealworms, house crickets, hand-trapped spiders, and bugs. Both vole species were fed standard mouse laboratory food. We used both sexes of the shrews for our experiment because they were difficult to trap; sexes were distributed equally over runs.

Adult common voles were paired in the laboratory at the beginning of each run (Table 2) and usually mated immediately after pairing. Pregnant females were released into enclosures for habituation $12 \mathrm{~d}$ after pairing. After $3 \mathrm{~d}$ of habituation, we sampled the faeces of the focus females to get a stress hormone baseline $(b$, Table 2$)$ on a natural grass diet. To minimise the influence of trapping stress, we checked traps every hour.

Each trapped female was placed into a sample chamber (diameter: $130 \mathrm{~mm}$, height: $100 \mathrm{~mm}$ ) with a metal bottom with holes $(5 \times 5 \mathrm{~cm})$ for a maximum of $2 \mathrm{~h}$ to get faecal samples. All excreta fell onto filter paper and were collected into an Eppendorf tube. We sampled the pre-trapping stress levels in faeces collected within $2 \mathrm{~h}$ of trapping to avoid the confounding effects of trapping stress itself, which appears in faeces after 3-4 h [71]. In common voles, the stress of retrieving and handling a caged animal produces a hormone metabolite peak in the faeces after $2 \mathrm{~h}$ (unpublished data). Tubes with faeces were immediately frozen at $-80^{\circ} \mathrm{C}$.

We added one treatment animal to each enclosure. In four cases (one NP, two RC, and one C), we had to stop the replicate, because the focus female had apparently terminated the pregnancy. In NP treatment enclosures, we placed a food station in the middle of the enclosure to provide mealworms and water for the shrew. A filter paper beneath each feeding station was surrounded by a

Table 2 Schedule of experimental steps and faecal sampling during each experimental run

\begin{tabular}{cll}
\hline Experimental day & Experimental steps & Faecal sampling \\
\hline $\mathbf{0}$ & voles paired in laboratory & \\
$\mathbf{3}$ & males removed & \\
$\mathbf{1 2}$ & pregnant females released into enclosures for habituation & b: baseline, prior to the experiment \\
$\mathbf{1 5}$ & treatment animals (NP, RC, C) added to enclosures & l: sample under treatment conditions, \\
$\mathbf{1 8}$ & females equipped with radio tags & parturition \\
$\mathbf{1 9 - 2 1}$ & parturition, nest site identification by radio telemetry & \\
$\mathbf{2 2 - 2 4}$ & detection of nest entrances by fogging, activity measurements & \\
$\mathbf{2 4}$ & by automatic transponder reading antennas & I: sample under treatment, with nestlings \\
\hline
\end{tabular}


permanent ink pad and used to check for footprints daily to confirm shrew presence.

On day 18 of pregnancy ( $3 \mathrm{~d}$ after adding the treatment animal), we collected a faecal sample from each focus female to determine the stress hormone level around parturition (I, Table 2). Females were equipped with radio telemetry tags (Biotrack, Wareham, UK) to locate their nest sites during parturition (days 19-21 of pregnancy).

After parturition, we counted burrow entrances using a fogging machine (N-110; Eurolite) with an odourless, biodegradable, non-irritant, and non-toxic fogging fluid (Fogging Fluid B; Eurolite). To monitor the presence of pitted animals (shrews and voles) at burrow entrances, we inserted circular antennas (type EUR 3120, diameter: $5 \mathrm{~cm}$, EURO I.D., Weilerswist, Germany) into each tunnel entrance (circa $5 \mathrm{~cm}$ deep) and measured passage activities for $3 \mathrm{~d}$. Antennas were connected to automatic radio-frequency identification transponder reading stations (type LID 665, EURO I.D.) powered in the field by a $12 \mathrm{~V}$ lead battery with a $5 \mathrm{~m}$ long cable.

On day 24 of the experimental run, we collected a faecal sample to estimate stress hormone levels of mothers with nestlings in the presence of treatment animals (II, Table 2). While mothers were in the sampling chamber, we excavated the nests and recorded the depth of the nest chamber, the number of entrances, and the number and weight of nestlings. All nests were recovered with healthy, living nestlings that re-joined their mother after the replicate. After the experiment, all treatment animals were released back to their capture site.

\section{Measurement of faecal corticosterone metabolites}

FCMs were extracted as described by Touma et al. [72] and analysed using 5 $\alpha$-pregnane-3ß,11ß,21-triol20-one enzyme immunoassays (for details see [73]). This method was validated for common voles prior to this study (Liesenjohann in prep.) following Touma et al. [72] for mice.

\section{Analyses and statistics}

To allow the animals to habituate, we began data acquisition $24 \mathrm{~h}$ after inserting the antennas into the tunnel entrances. Activity bouts of the animals were defined as active periods framed by inactive periods of at least $30 \mathrm{~min}$ [74]. Measured variables of burrow architecture (number of entrances and depth of nest) and of mothers' activity at burrow entrances (mean number of readings per bout, mean duration of bout in seconds, and passage speed in readings per second) originated from a single burrow. Maternal activity over $36 \mathrm{~h}$ was analysed.

All variables were normally distributed except the number of burrow entrances (Kolmogorov-Smirnov $Z=1.54$, $P=0.018$ ), which was Poisson distributed (KolmogorovSmirnov $Z=1.03, P=0.24$ ) and therefore analysed using a general linear model (GLM). All other variables were analysed using analysis of variance (ANOVA; depth of the nest site) or multivariate analysis of variance (MANOVA; the three variables of burrow entrance activity, see above). The three models, GLM, MANOVA, and ANOVA, included treatment as a fixed factor with three levels: NP, $\mathrm{RC}$, and $\mathrm{C}$.

The FCMs of vole mothers and their effects on body weight were analysed with two-factorial GLMs with treatment and sampling as fixed factors.

The influences of origin (lab born vs. wild caught), age (over-wintered vs. born that year) and experience (second litter vs. $>2$ litters) of mothers on all dependent variables were tested using ANOVAs or GLMs (depending on their distributions), but none of these factors had a significant impact and they are not discussed further. The number of nestlings was not significantly influenced by any treatment. For all statistical analyses, SPSS for Windows 19.x (IBM, Chicago, IL, USA) was used.

\section{Competing interests}

All authors declare that they have no competing interests.

\section{Authors' contributions}

$M L$ participated in the study design, carried out the field study, extracted FCMs, conducted statistical analyses, and drafted the manuscript. TL worked in the field and helped with statistical analysis. RP participated in the faecal sampling design and analysed the FCMs. JAE conceived of the study design. All authors corrected and improved the manuscript. All authors read and approved the final manuscript.

\section{Acknowledgements}

We thank Prof. Fritz Trillmich for providing his laboratory at the University of Bielefeld, Germany, for the FCM extractions and Elke Hippauf for technical support with the extractions. This study was supported by the German Science Foundation (grant ec361/4-1 to JAE). Permission for animal experiments was granted to Prof. J. A. Eccard, University of Bielefeld (22.5.2007), according to §8a Tierschutzgesetz (TSchG, animal protection law): "Analysis of direct interactions between voles and shrews", by the Nature Conservation Authority of North Rhine-Westphalia, Germany (permission number: 9.93.2.10.42.07.069).

\section{Author details}

'Department of Animal Ecology, University of Potsdam, Maulbeerallee 1, D-14469 Potsdam, Germany. ${ }^{2}$ Department of Natural Sciences Biochemistry, University of Veterinary Medicine, Veterinaer-Platz 1, A-1210 Vienna, Austria.

Received: 12 April 2013 Accepted: 4 September 2013

Published: 8 September 2013

\section{References}

1. Connell J: Diversity and the coevolution of competitors, or the ghost of competition past. Oikos 1980, 35(2):131-138.

2. Mitchell WA, Abramsky Z, Kotler BP, Pinshow B, Brown JS: The effect of competition on foraging activity in desert rodents - theory and experiments. Ecology 1990, 71(3):844-854.

3. Amarasekare P: Interference competition and species coexistence. Proc Royal Soc 2002, 269(1509):2541-2550.

4. Peiman KS, Robinson BW: Ecology and evolution of resource-related heterospecific aggression. Q Rev Biol 2010, 85(2):133-158.

5. Eccard JA, Ylönen H: Direct interference or indirect exploitation? An experimental study of fitness costs of interspecific competition in voles. Oikos 2002, 99(3):580-590.

6. Eccard JA, Ylönen $\mathrm{H}$ : Interspecific competition in small rodents: from populations to individuals. Evol Ecol 2003, 17(4):423-440. 
7. Martin TE: Fitness costs of resource overlap among coexisting bird species. Nature 1996, 380(6572):338-340.

8. Archer J: The behavioural biology of aggression. Cambridge: Cambridge University Press; 1988.

9. Palomares F, Caro TM: Interspecific killing among mammalian carnivores. Am Nat 1999, 153(5):492-508.

10. Martin TE: Avian life-history evolution in relation to nest sites, nest predation, and food. Ecol Monogr 1995, 65(1):101-127.

11. Martin TE: Avian life-history evolution has an eminent past: Does it have a bright future? Auk 2004, 121(2):289-301.

12. Martin TE, Li PJ: Life-history traits of open-nesting vs cavity-nesting birds. Ecology 1992, 73(2):579-592.

13. Montgomerie RD, Weatherhead PJ: Risks and rewards of nest defense by parent birds. Q Rev Biol 1988, 63(2):167-187.

14. Ricklefs RE: Natural selection and development of mortality rates in young birds. Nature 1969, 223(5209):922.

15. Martin TE: Nest predation and nest sites - new perspectives on old patterns. Bioscience 1993, 43(8):523-532.

16. Sih A, Crowley P, Mcpeek M, Petranka J, Strohmeier K: Predation, competition, and prey communities - a review of field experiments. Annu Rev Ecol Evol Syst 1985, 16:269-311.

17. Hansell M: Bird nests and construction behaviour. Cambridge, U.K.: Cambridge University Press; 2000

18. Lima SL: Predators and the breeding bird: behavioral and reproductive flexibility under the risk of predation. Biol Rev 2009, 84(3):485-513.

19. Martin TE, Roper JJ: Nest predation and nest-site selection of a western population of the hermit thrush. Condor 1988, 90(1):51-57.

20. Lima SL: Stress and decision making under the risk of predation: Recent developments from behavioral, reproductive, and ecological perspectives. Stress and Behavior 1998, 27:215-290.

21. Schoener TW: Field experiments on interspecific competition. Am Nat 1983, 122(2):240-285.

22. Ziv Y, Abramsky Z, Kotler BP, Subach A: Interference competition and temporal and habitat partitioning in 2 gerbil species. Oikos 1993, 66(2):237-246

23. Wolff JO: Why are female small mammals territorial. Oikos 1993, 68 (2):364-370.

24. Kinlaw A: A review of burrowing by semi-fossorial vertebrates in arid environments. J Arid Environ 1999, 41(2):127-145.

25. Andersson M, Wiklund CG, Rundgren $\mathrm{H}$ : Parental defense of offspring - a model and an example. Anim Behav 1980, 28(May):536-542.

26. Clutton-Brock: The evolution of parental care. Princeton: Princeton University Press; 1991.

27. Trivers RL: Mother-offspring conflict. Am Zool 1972, 12(4):648-648.

28. Lima SL, Valone TJ, Caraco T: Foraging-efficiency predation-risk trade-off in the Grey squirrel. Anim Behav 1985, 33(Feb):155-165.

29. Stearns SC: Trade-offs in life-history evolution. Funct Ecol 1989, 3(3):259-268.

30. Magnhagen C: Conflicting demands in gobies - when to eat, reproduce, and avoid predators. Mar Behav Physiol 1993, 23(1-4):79-90.

31. Swaisgood RR, Rowe MP, Owings DH: Antipredator responses of California ground squirrels to rattlesnakes and rattling sounds: the roles of sex, reproductive parity, and offspring age in assessment and decisionmaking rules. Behav Ecol Sociobiol 2004, 55(4):410-413.

32. Ylönen $\mathrm{H}$, Horne $\mathrm{T}$ : Infanticide and effectiveness of pup protection in bank voles: does the mother recognise a killer? Acta ethologica 2002, 4(2):97-101.

33. Koskela E, Juutistenaho P, Mappes T, Oksanen TA: Offspring defence in relation to litter size and age: Experiment in the bank vole Clethrionomys glareolus. Evol Ecol 2000, 14(2):99-109.

34. Monclus R, Rödel HG: Influence of different individual traits on vigilance behaviour in European rabbits. Ethology 2009, 115(8):758-766.

35. Wolff RJ: Mating behavior and female choice - their relation to social-structure in wild caught house mice (Mus musculus) housed in a semi-natural environment. J Zool 1985, 207(Sep):43-51.

36. Dale S, Gustavsen R, Slagsvold T: Risk taking during parental care: A test of three hypotheses applied to the pied flycatcher. Behav Ecol Sociobiol 1996, 39(1):31-42.

37. Listoen C, Karlsen RF, Slagsvold T: Risk taking during parental care: a test of the harm-to-offspring hypothesis. Behav Ecol 2000, 11(1):40-43.
38. Getz L, Larson C, Lindstrom K: Blarina brevicauda as a predator on nestling voles. J Mammal 1992, 73(3):591-596.

39. Fulk G: Effect of shrews on space utilization of voles. J Mammal 1972, 53(3):461.

40. Hawlena D, Schmitz OJ: Physiological stress as a fundamental mechanism linking predation to ecosystem functioning. Am Nat 2010, 176(5):537-556.

41. Cresswell W: Nest predation: The relative effects of nest characteristics, clutch size and parental behaviour. Anim Behav 1997, 53:93-103.

42. Lomascolo SB, Monmany AC, Malizia A, Martin TE: Flexibility in nest-site choice and nesting success of Turdus rufiventris (Turdidae) in a montane forest in Northwestern Argentina. Wilson J Ornithol 2010, 122(4):674-680.

43. Smith AP, Quin DG: Patterns and causes of extinction and decline in Australian conilurine rodents. Biol Conserv 1996, 77(2-3):243-267.

44. Bronner GN: Burrow system characteristics of seven small mammal species (Mammalia: Insectivora; Rodentia; Carnivora). Koedoe 1992. 35(1):125-128.

45. Harper S, Batzli G: Effects of predators on structure of the burrows of voles. J Mammal 1996, 77(4):1114-1121

46. Rödel HG, Starkloff A, Seltmann MW, Prager G, von Holst D: Causes and predictors of nest mortality in a European rabbit population. Mamm Biol 2009, 74(3):200-211.

47. Monclus $R$, Rödel $H G$, von Holst D: Fox odour increases vigilance in European rabbits: A study under semi-natural conditions. Ethology 2006, 112(12):1186-1193

48. Monclus R, Rödel HG, Von Holst D, De Miguel J: Behavioural and physiological responses of naive European rabbits to predator odour. Anim Behav 2005, 70:753-761.

49. Reynolds TD, Wakkinen WL: Characteristics of the burrows of 4 species of rodents in undisturbed soils in southeastern Idaho. Am Midl Nat 1987, 118(2):245-250.

50. Eilam D, Dayan T, Ben-Eliyahu S, Schulman I, Shefer G, Hendrie CA: Differential behavioural and hormonal responses of voles and spiny mice to owl calls. Anim Behav 1999, 58:1085-1093.

51. Wingfield JC, Ramenofsky M: Hormones and the behavioral ecology of stress. Sheffield: Sheffield Academic; 1999.

52. Blanchard RJ, Nikulina JN, Sakai RR, McKittrick C, McEwen B, Blanchard DC: Behavioral and endocrine change following chronic predatory stress. Physiol Behav 1998, 63(4):561-569.

53. Monclus R, Rödel HG, Palme R, Von Holst D, de Miguel J: Non-invasive measurement of the physiological stress response of wild rabbits to the odour of a predator. Chemoecology 2006, 16(1):25-29.

54. Sheriff MJ, Dantzer B, Delehanty B, Palme R, Boonstra R: Measuring stress in wildlife: techniques for quantifying glucocorticoids. Oecologia 2011, 166(4):869-887

55. Ylönen $\mathrm{H}$, Eccard JA, Jokinen I, Sundell J: Is the antipredatory response in behaviour reflected in stress measured in faecal corticosteroids in a small rodent? Behav Ecol Sociobiol 2006, 60(3):350-358

56. Bajkowska U, Chetnicki W, Fedyk S: Breeding of the common shrew, Sorex araneus, under laboratory conditions. Folia Zool 2009, 58(1):1-8.

57. Churchfield S: The natural history of shrews. London: Christopher Helm (Publishers) Ltd; 1990.

58. Niethammer J, Krapp F: Handbuch der Säugetiere Europas - Rodentia II. 2/I, 1st edition. Wiesbaden: Akademische Verlagsgesellschaft; 1982.

59. Churchfield S: Subterranean foraging and burrowing activity of the common shrew. Acta Theriol 1980, 25(32-4):451-459.

60. Ruzic A: Spitzmäuse als Räuber der Feldmaus Microtus arvalis (Pallas, 1779). Säugetierkundliche Mitteilungen 1971, 19:366-370.

61. Liesenjohann M, Liesenjohann T, Trebaticka L, Haapakoski M, Sundell J, Ylonen $\mathrm{H}$, Eccard JA: From interference to predation: type and effects of direct interspecific interactions of small mammals. Behav Ecol Sociobiol 2011, 65(11):2079-2089.

62. Mayer AD: Maternal responsiveness and nest defense during the prepartum period in laboratory rats. Ann N Y Acad Sci 1986, 474:216-225.

63. Mclean IG: Plugging of nest burrows by female Spermophilus columbianus. J Mammal 1978, 59(2):437-439.

64. Caine NG, Weldon PJ: Responses by red-bellied tamarins (Saguinus labiatus) to fecal scents of predatory and non-predatory neotropical mammals. Biotropica 1989, 21(2):186-189.

65. Roberts SC: Social influences on vigilance in rabbits. Anim Behav 1988, 36:905-913. 
66. Laundre JW, Hernandez L, Altendorf KB: Wolves, elk, and bison: reestablishing the "landscape of fear" in Yellowstone National Park, USA. Canadian Journal of Zoology-Revue Canadienne De Zoologie 2001 79(8):1401-1409.

67. Murray DL: Differential body condition and vulnerability to predation in snowshoe hares. J Anim Ecol 2002, 71(4):614-625.

68. Winnie J, Creel S: Sex-specific behavioural responses of elk to spatial and temporal variation in the threat of wolf predation. Anim Behav 2007, 73:215-225

69. Jones M, Dayan T: Foraging behavior and microhabitat use by spiny mice, Acomys cahirinus and A. russatus, in the presence of Blanford's fox (Vulpes cana) odor. J Chem Ecol 2000, 26(2):455-469.

70. Connell JH: On the prevalence and relative importance of interspecific competition - evidence from field experiments. Am Nat 1983, 122(5):661-696.

71. Harper J, Austad S: Effect of capture and season on fecal glucocorticoid levels in deer mice (Peromyscus maniculatus) and red-backed voles (Clethrionomys gapperi). Gen Comp Endocrinol 2001, 123(3):337-344.

72. Touma C, Palme R, Sachser N: Analyzing corticosterone metabolites in fecal samples of mice: a noninvasive technique to monitor stress hormones. Horm Behav 2004, 45(1):10-22.

73. Touma C, Sachser N, Mostl E, Palme R: Effects of sex and time of day on metabolism and excretion of corticosterone in urine and feces of mice. Gen Comp Endocrinol 2003, 130(3):267-278.

74. Eccard JA, Liesenjohann T: Foraging decisions in risk-uniform landscapes. PLoS One 2008, 3(10). doi:10.1371/journal.pone.0003438.

doi:10.1186/1472-6785-13-33

Cite this article as: Liesenjohann et al: Differential behavioural and endocrine responses of common voles (Microtus arvalis) to nest predators and resource competitors. BMC Ecology 2013 13:33.

\section{Submit your next manuscript to BioMed Central and take full advantage of:}

- Convenient online submission

- Thorough peer review

- No space constraints or color figure charges

- Immediate publication on acceptance

- Inclusion in PubMed, CAS, Scopus and Google Scholar

- Research which is freely available for redistribution 